\title{
Identification Of Core Indicators Of The Dynamic Efficiency Evaluation Method of Design Solutions
}

\author{
Aleksandr Sergeevich Semenov \\ Saint-Petersburg mining university, \\ Russian Federation; \\ Vladimir Sergeevich Kuznetsov \\ Saint-Petersburg mining university, \\ Russian Federation;
}

\begin{abstract}
Optimization methods in mining industry, taking into account the time factor develop abroad from the end of 19 century. However, in the context of policy centrally planned economy development of dynamic methods substantially restrained. In the last decade have developed research in the field of dynamic methods for solving design problems of the domestic mining industry, including a number of official recommendations $[1,2]$. However, the formation of a national market economy, especially the contemporary stage of the open mining (particularly complex), the development of mineral resources markets require constant adjustment and improvement of dynamic design techniques of quarries. In the mining industry specific investments, establishing the capital investment is several times bigger than the in manufacturing industries. Dynamic evaluation methods taking into account the time factor can help you determine the value of the investment in time unlike the way economic evaluation methods. Mineral markets there is a tendency for problems with the deterioration of the of economic indicators of development. This is due to the oxygen dissipated rich deposits, increasing depth development, involvement in the development of minerals with lower quality involved and content of useful components, to be found in the more difficult geological and location conditions. Investment opportunities of the development mineral-raw materials base have significant limitations, the result of which is a disproportion between the mining, metallurgical or processing capacity.
\end{abstract}

Keywords: Risk, management, design, solution, quarry, decision-making project, risk analysis, dynamic evaluation methods, economic indicators

\section{INTRODUCTION}

More comprehensive development and utilization of mineral resources located in the sphere of influence of planned and produced by mining, is achieved with a comprehensive design and development of complex fields [5, 6]. To expand the area of deposits, which are economically feasible, open cast mine, you must shoot seek to increase the proportion of the total mineral rock quarries; inclusion of new sources of mineral resources, such as off-balance sheet reserves, overburden-passing fossil, mineral processing waste; not previously retrieved accompanying climbed components.

The more extracted from ores by-product of useful components, the lower boundary becomes the content of the main useful components, along with the rise in deposits of minerals, a possible career in the exponential performance of the final product and economic efficiency of the development processing. 
With the continued performance career on minerals appears to reduce the sinking rate, increase exploitation term deposits if necessary and reduce the operational stripping ratio.

Involvement in the development of associated minerals, with unchanged performance career on a mountain mass, lets you increase the performance of the quarry for commodity products and mineral resources, increase the possible depth career, mineral reserves.

The basis of the dynamic method is to identify the following key indicators $[2,9,10]$ :

1. Net present value (NPV), sold at the market of mineral raw materials for the whole period of refining the extracted minerals deposits or learned useful components;

2. Rate of return or internal rate of return (IRR) for the implementation of the project of open-cast.

3. The payback period of investment (PBP).

\section{METHODOLOGY}

Accounting for changes in the value of investments in time sponsored by using the discounting factor serving to bring economic indicators, dating to the same time

$$
q^{-n}=(1+i)^{-n} \quad
$$

$\mathrm{q}^{-\mathrm{n}}$ - discounting factor (discount);

i - interest rate (interest);

$\mathrm{n}$ - sequence number of the year evaluation.

To determine the net present value (NPV), realizing the mineral market, for the entire period of refining and of extracted minerals or minerals extracted, net current profit-net cash flow(NC - net cash flow) to discount taking into account that the interest rates (interest rate (i)), and the total investment (I) shall be deducted from the amount of discounted net current profit.

Thus, in a general form for career where one kind of mineral is extracted (uniform deposit)

$$
N P V_{c}=\sum_{j=1}^{N}\left(N C_{j} \cdot q_{j}^{-n}\right)-\sum_{\omega=1}^{N_{C}}\left(I_{\omega} \cdot q_{\omega}^{-n}\right)
$$

$\mathrm{j} \in \mathrm{k}_{1}, \omega \in \mathrm{k}_{2}$,

$\mathrm{k}_{1}=\{1,2,3, \ldots, \mathrm{N}\}$ - the duration of the practicing quarry, years;

$\mathrm{k}_{2}=\left\{1,2,3, \ldots, \mathrm{N}_{\mathrm{c}}\right\}$ - investment duration, years;

$\mathrm{q}^{-\mathrm{n}}$ - discounting factor of net current profit in $\mathrm{j}$-th year;

$\mathrm{q}^{-\mathrm{n}_{\omega}}$ - discounting factor of investment in $\omega$-th year;

$\mathrm{NC}_{\mathrm{j}}$ - net current profit from development of career in the $\mathrm{j}$-th year, after accounting for interest rate payments and taxes;

$I_{\omega}$ - the value of investments in $\omega$-th year.

Investment can take place prior to the commencement of the maintenance period and in this case equation (2) will take the following form

$$
N P V^{\prime}=\sum_{j=1}^{N}\left(N C_{j} \cdot q_{j}^{-n}\right)-\sum_{j^{\prime}=0}^{t} I_{j^{\prime}} \cdot q_{j^{\prime}}^{-n^{\prime}}
$$


$\mathrm{j} /=(1,2, \ldots, \mathrm{n} / \mathrm{)}$ - sequence number year of investing before the start of the maintenance period in his career;

$\mathrm{t}$ - investment duration, years.

When developing complex deposits net present value of the project realization career

$$
N P V_{c}=\sum_{f=1}^{r} \sum_{z=1}^{d} \sum_{j=1}^{N}\left(N C_{j z f} \cdot q_{j z f}^{-n}\right)-\sum_{f=1}^{r} \sum_{z=1}^{d} \sum_{\omega=1}^{N_{C}}\left(I_{\omega z f} \cdot q_{\omega z f}^{-n}\right)
$$

$\mathrm{f} \in \mathrm{k}_{1}, \quad \mathrm{z} \in \mathrm{k}_{2}, \quad \mathrm{j} \in \mathrm{k}_{3}, \quad \omega \in \mathrm{k}_{4}$

$\mathrm{k}_{1}=\{1,2,3, \ldots, \mathrm{r}\}, \mathrm{k}_{2}=\{1,2,3, \ldots, \mathrm{d}\}$,

$\mathrm{k}_{3}=\{1,2,3, \ldots, \mathrm{N}\}, \mathrm{k}_{4}=\left\{1,2,3, \ldots, \mathrm{N}_{\mathrm{c}}\right\}$,

$\mathrm{k}_{1}=\{1,2,3, \ldots, \mathrm{r}\}$ - the number of minerals mined in the quarry;

$\mathrm{k}_{2}=\{1,2,3, \ldots, \mathrm{d}\}-$ number of useful components, derived from one type of mineral being mined in the quarry;

$\mathrm{k}_{3}=\{1,2,3, \ldots, \mathrm{N}\}$ - the duration of the career, years;

$\mathrm{k}_{4}=\left\{1,2,3, \ldots, \mathrm{N}_{\mathrm{c}}\right\}$ - duration of investment, years;

$\mathrm{NC}_{\mathrm{jzf}}$ - net current profit from realization of z-th useful component extracted from $\mathrm{f}$-th kinds of ore extracted in a career in the $\mathrm{j}$-th period;

$\mathrm{q}^{-\mathrm{n}_{\mathrm{jzf}}}=(1+\mathrm{i})^{-\mathrm{n}}$ - discounting factor of net current profit $\mathrm{z}$-th useful component extracted from $\mathrm{f}$ th kinds of ore extracted in career in the j-th period;

$\mathrm{q}^{-\mathrm{n}_{\mathrm{w} \mathrm{f}}}=(1+\mathrm{i})^{-\mathrm{n}}$ - discounting factor in investment $\omega$-th year in obtaining $\mathrm{z}$-th useful component extracted from $\mathrm{f}$-th kinds of ore extracted in the quarry;

i - interest rate (interest);

$\mathrm{I}_{\mathrm{w} \mathrm{f}}$ - the value of investment in design, construction and operation of a career in the $\omega$-th year to obtain z-th useful component extracted from $\mathrm{f}$ - th kind of ore.

Net present value (NPV) shows potential investors the value of investments in the development of the field, to which have not yet been developed, taking into account the following factors:

- the amount of total investment in design, construction and operation quarry, developing the deposit;

- individual annual net current profit, defined as channeled by current profit after taxes and a possible discount rate (interest rate);

- year $\left(\mathrm{n}_{\mathrm{j}}\right)$ determine the present net current profit;

- the risk inherent in choosing investment interest rate (interest rate).

In table 1 and figure 1 is an example of the calculation of the net present value for the project, with the largest one-time career summary of investments in mining, held immediately before the commencement of construction career $\mathrm{I}_{\mathrm{c}}=430$ million rubles and equal values of annual net current profit.

Under the net present value career development project refers to the economic cost of the project, calculated by summing the costs and revenues that its implementation would bring during the time of its functioning, and subtracting that amount from the last first.

If the net present value calculations prove positive, the project wives be profitable. In doing so, future costs and revenues should be on the appropriate discount rate. It is also advisable to 
take into account simultaneously the internal rates of return of the project. For the considered example the net present value of project

$$
N P V=\sum_{j=1}^{10}\left(N C_{j} \cdot q_{j}{ }^{-n}\right)-I_{C}=(503-430) 106=73 \text { million rubles }
$$

Therefore, if the investor expects to make money on interest rate $15 \%$ of your capital, it should evaluate the project in 73 million. rub. before you make an investment. The net present value of the implementation of the project depends mainly on the size of the interest rate which developed mining countries usually does not exceed $15 \%$ for open mining.

Table 1. Annual present net profit

\begin{tabular}{|c|r|r|r|l|l|l|l|l|l|l|}
\hline Year & $\mathbf{1}$ & $\mathbf{2}$ & $\mathbf{3}$ & $\mathbf{4}$ & $\mathbf{5}$ & $\mathbf{6}$ & $\mathbf{7}$ & $\mathbf{8}$ & $\mathbf{9}$ & $\mathbf{1 0}$ \\
\hline $\begin{array}{c}\text { Net current }(\mathrm{NCj}) \\
\text { Profit, million rubles }\end{array}$ & 100 & 100 & 100 & 100 & 100 & 100 & 100 & 100 & 100 & 100 \\
\hline $\begin{array}{c}\text { Discounting }\left(\mathrm{q}_{\mathrm{j}}^{-\mathrm{n}}\right) \\
\text { factor (i } 0,15)\end{array}$ & 0,87 & 0,76 & 0,66 & 0,57 & 0,5 & 0,43 & 0,38 & 0,33 & 0,28 & 0,25 \\
\hline $\begin{array}{c}\text { Net current }\left(\mathrm{NC}_{\mathrm{j}} \mathrm{q}_{\mathrm{j}}^{-\mathrm{n}} \text { ) }\right. \\
\text { discounted profit, million rubles }\end{array}$ & 87 & 76 & 66 & 57 & 50 & 43 & 38 & 33 & 28 & 25 \\
\hline
\end{tabular}

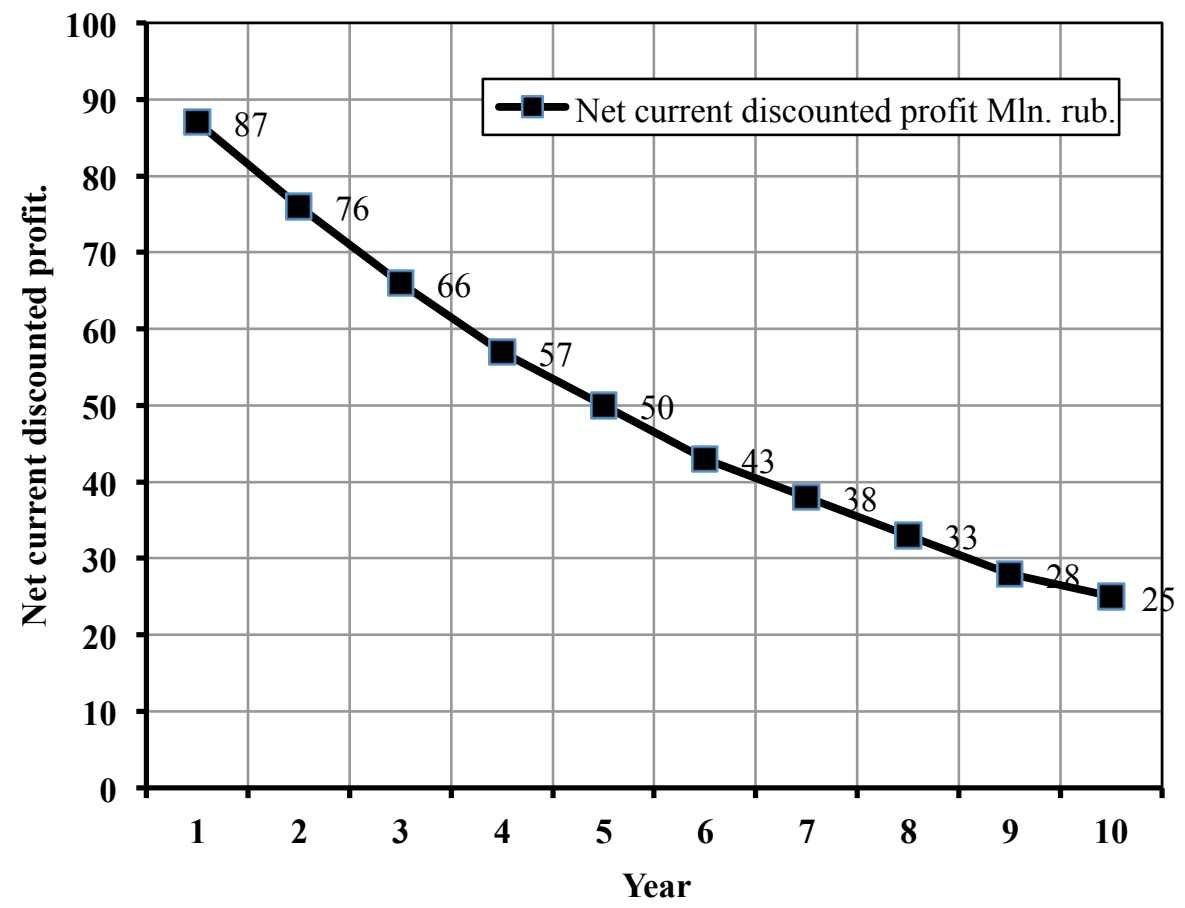

Figure 1. Change in the time schedule of net current profit

As a rule, the Government's level of commitment is chosen as a long-term investment with minimal risk. If the obligations represented $10 \%$ interest rate, the discount factor for this project must be at least $15 \%$ to compensate for the risk of involving career in operation [5].

Results you are presented in the table 1, show that the discounted net current profit through the 10 years will be evaluated only in $29 \%$ of the first year. While developing a career in 25 years, with a fixed interest rate of $15 \%$, the last 5 years $(20 \%$ of the total duration of the construction) will make up only $3 \%$ of the total net current profit. 
For mining projects in our country, in the case of foreign financing, interest rates can exceed $30 \%$. Norm for discounting and interest rate on investments do not always coincide. In the midst of the crisis phenomena in the economy and high inflation in determining the discount rules, you can navigate to the deposit rate in the most stable foreign currency (Euro or United States dollar).

Receipt of annual current profit equal during the assessment allows simplify calculations using annual factor present value - annuity factor $\left(b_{n}\right)[6,7,8]$

$$
b_{n}=\frac{q^{n}-1}{q^{n}(q-1)}
$$

$\mathrm{q}=1+\mathrm{i}$.

Thus, the formula 2 can be represented

$$
\mathrm{NPV}=\mathrm{CF} \cdot \mathrm{bn}-\mathrm{I} \text {, }
$$

CF - annual current profit (cash flow) from deposit, rubles

Consider the method for determining the rate of return of the project careers in justifying investments in building career. Let's say, for open-cast mining of ore deposits needed to attract investments in the amount of $\mathrm{I}=500$ million rub. Deposits of ore reserves and demand on the market for this type of mineral raw material allows to estimate the time in 12 years. Define the net present value of the project realization with knowledge of exclusions career interest rate $10 \%, 20 \%, 30 \%$ and the net current profit per annum equal NC $=120$ million rub. Investments are held just before the start of lump sum construction career.

1. Determine the amount of the annuity factor, when $n=12$ years, according to the formula 6

$$
\begin{array}{ll}
\text { for } \mathrm{i}=0,1 & b_{n 1}=\frac{1,1^{12}-1}{1,1^{12}(1,1-1)}=6,81 ; \\
\text { for } \mathrm{i}=0,2 & \mathrm{~b}_{\mathrm{n} 2}=4,44 ; \\
\text { for } \mathrm{i}=0,3 & \mathrm{~b}_{\mathrm{n} 3}=3,19 .
\end{array}
$$

2. Determine the value of the net present value of the project realization careers for different values of the interest rate

$$
\begin{array}{ll}
\text { for } \mathrm{i}=0,1 & \mathrm{NPV}_{1}=120 \cdot 6,81-500=317,2 \text { million rubles } \\
\text { for } \mathrm{i}=0,2 & \mathrm{NPV}_{2}=120 \cdot 4,44-500=28 \text { million rubles } \\
\text { for } \mathrm{i}=0,3 & \mathrm{NPV}_{3}=120 \cdot 3,19-500=-117,2 \text { million rubles } .
\end{array}
$$

3. Building plot of the net present value of the project realization of career interest rates figure 2 .

Curve NPV $=\mathrm{f}$ (i) crosses the $\mathrm{x}$-axis at the point corresponding to the value of $\mathrm{i}=21.7 \%$ where $\mathrm{NPV}=0$. This conforms to the profitability of the project. 
The magnitude of the project rate of return is determined by the total equity net present current profit (in some cases present gross current profit) largest summary of investment: (at unequal annual CF)

$$
\sum_{j=1}^{N}\left(N C_{j} \cdot q_{j}{ }^{-n}\right)=\sum_{\omega=1}^{N_{C}} I_{\omega} \cdot q_{\omega}{ }^{-n}
$$

(at equal annual CF)

$$
\mathrm{CF} \cdot \mathrm{bn}=\mathrm{I} \quad \text {, }
$$

$b_{n}-$ annuity factor.

When the project has uneven annual current profit value, rate of return cannot be calculated directly, but must be determined through an iterative process.

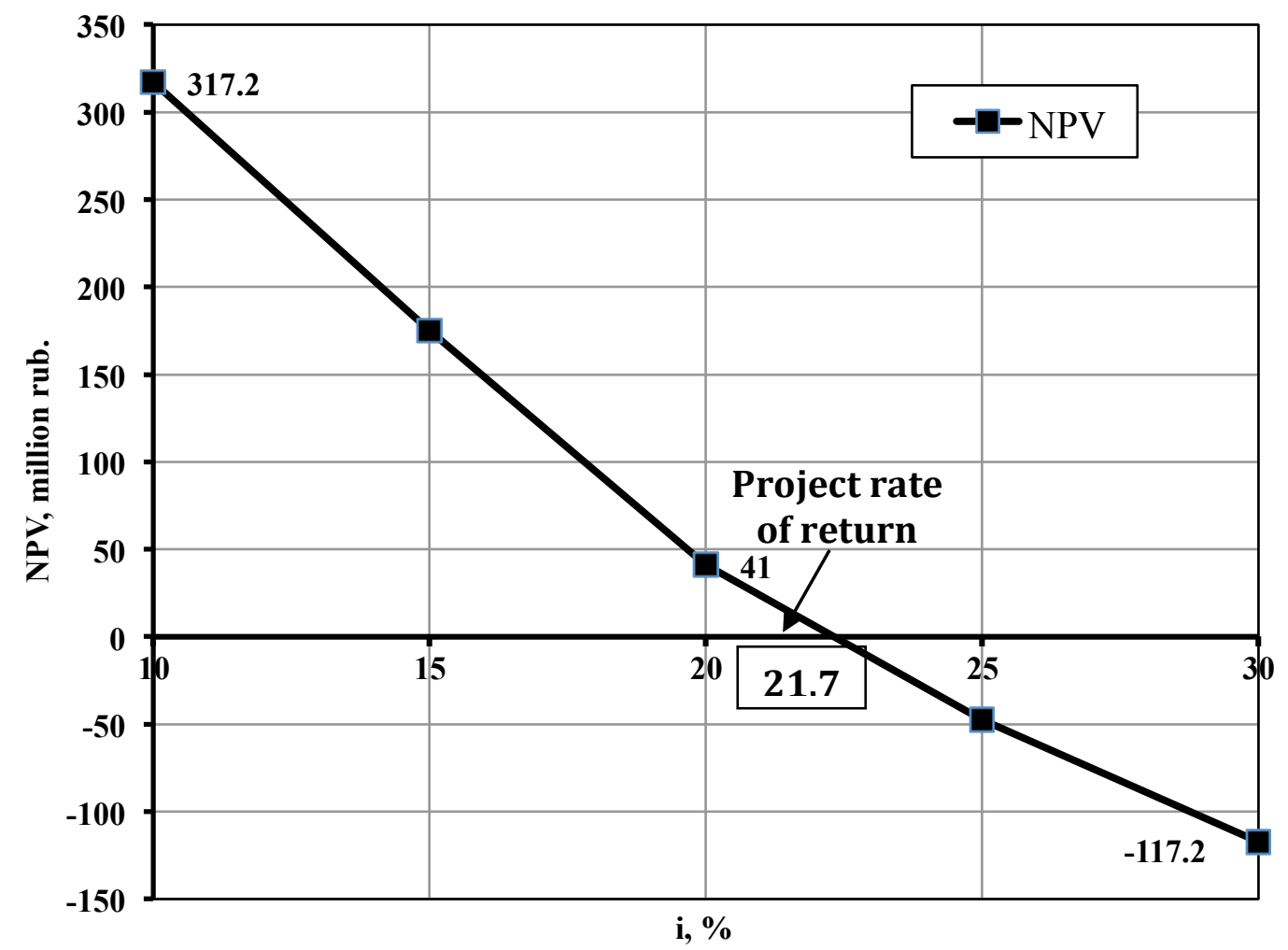

Figure 2. Diagram of dependence of net present value of the project realization of career interest rate

In the table 2 provides an example of the calculation of discounted net current profit for the project career, for $\mathrm{i}=0.2$. Investments in the amount of $\mathrm{I}=280$ million rub. held just before the start of lump sum construction career.

The data presented in table 2 permit to determine the rate of return of the project career

$$
\begin{gathered}
\sum_{j=1}^{8}\left(N C_{j} \cdot q_{j}^{-n}\right)=305,0 \text { million rubles } \\
I-\sum_{j=1}^{8}\left(N C_{j} \cdot q_{j}^{-n}\right)=280-305=-25 \text { million rubles }
\end{gathered}
$$


Table 2.Annual net profit project present career when $\mathrm{i}=0.2$.

\begin{tabular}{|c|c|c|c|c|c|c|c|c|c|}
\hline Year & $\mathbf{0}$ & 1 & 2 & 3 & 4 & 5 & 6 & 7 & 8 \\
\hline Investment (I), million rubles & 280 & & & & & & & & \\
\hline Net current $\left(\mathrm{NC}_{\mathrm{j}}\right)$ profit, million rubles & & 65 & 95 & 90 & 85 & 80 & 75 & 70 & 65 \\
\hline Discounting $\left(\mathrm{q}_{\mathrm{j}}^{-\mathrm{n}}\right)$ factor $(\mathrm{i}=0.2)$ & & 0,83 & 0,69 & 0,58 & 0,48 & 0,4 & 0,34 & 0,28 & 0,23 \\
\hline $\begin{array}{l}\text { Net current }\left(\mathrm{NC}_{\mathrm{j}} \mathrm{q}_{j} \mathrm{i}^{-\mathrm{n}}\right) \text { discounted } \\
\text { profit, million rubles }\end{array}$ & & 53,9 & 65,6 & 52,2 & 40,8 & 32 & 25,5 & 19,6 & 15,3 \\
\hline
\end{tabular}

Thus obtained a negative result and net current profit may not be discount further, therefore, as a next step, take a larger interest rate, $\mathrm{i}=0.25$. In the table 3 presents the results of a calculation of discounted net current profit at $\mathrm{i}=0.25$.

Based on the results of the calculations presented in the table 3 determine the rate of return of the project career when $\mathrm{i}=0.25$.

$$
\sum_{j=1}^{8}\left(N C_{j} \cdot q_{j}^{-n}\right)=265,3 \text { million rubles }
$$

Therefore, $I-\sum_{j=1}^{8}\left(N C_{j} \cdot q_{j}^{-n}\right)=280-265,3=+14,7$ million rubles , equality has a positive.

In this case the net present profit to discount too much.

Table 3. Annual net profit project present career when $\mathrm{i}=0.25$.

\begin{tabular}{|c|c|c|c|c|c|c|c|c|}
\hline Year & $\mathbf{1}$ & $\mathbf{2}$ & $\mathbf{3}$ & $\mathbf{4}$ & $\mathbf{5}$ & $\mathbf{6}$ & $\mathbf{7}$ & $\mathbf{8}$ \\
\hline Net current $\left(\mathrm{NC}_{\mathrm{j}}\right)$ profit, million rubles & 65 & 95 & 90 & 85 & 80 & 75 & 70 & 65 \\
\hline Discounting $\left(\mathrm{q}_{\mathrm{j}}{ }^{-\mathrm{n}}\right)$ factor $(\mathrm{i}=0.2)$ & 0,8 & 0,64 & 0,51 & 0,41 & 0,33 & 0,26 & 0,21 & 0,17 \\
\hline $\begin{array}{c}\text { Net current }\left(\mathrm{NC}_{\mathrm{j}} \mathrm{q}_{\mathrm{j}}{ }^{-\mathrm{n}}\right) \text { discounted profit, } \\
\text { million rubles }^{-}\end{array}$ & 52 & 60,8 & 45,9 & 34,9 & 26,4 & 19,5 & 14,7 & 11,1 \\
\hline
\end{tabular}

Project rate of return is determined when performing equality

$$
I-\sum_{j=1}^{N}\left(N C_{j} \cdot q_{j}{ }^{-n}\right)=0
$$

For the project rate of return of the project lies between 20 and $25 \%$. A solution might be found simple interpolation both graphically and analytically.

Rate of return for the project, the open development of the field is determined by the sum of the discounted net current profit, equal to the largest investment in the project.

When carrying out the justification of investments into construction careers the source data are limited and the stochastic nature. For example, at this stage, the design can be taken the average mineral content during the whole period of refining field. For values of investment and 
operating costs and communication costs pits perhaps the assumption of their permanence in time of construction career, until the project discontinued productivity.

The interest rate, and as a result taxes always are unevenly distributed by operating time career, so inevitably the assessment project career involved uneven annual current profit. However, if we assume the magnitude of annual profit from the production activities of fourteen permanent, the rate of return can be determined from the expression

$$
b_{n}=\frac{I}{O P_{c}} \quad,
$$

$\mathrm{OP}_{\mathrm{C}}$ - profit from production activities (conditionally net profit);

$b_{n}-$ annual present value factor-factor rents.

Consider the methods of determining the lowest possible (edge) medium mineral constituents in the ore, providing necessary under the terms of the mineral market rate of return of the project. Consideration of this technique feasible to assess the real example of ore deposit.

Evaluation procedure methodically following may be adopted:

1. Defines the possible annual performance according to the ore-career $\left(\mathrm{A}_{\mathrm{P}}\right)$

$$
A_{p}=\frac{G_{p} \cdot p^{\prime}}{T_{o}}
$$

2. Annual present value factor (for $i=0.24$ ) is determined by the formula (5)

3. Annual profit from production activities (formula (9)).

4. Specific annual profit

$$
P_{o}=\frac{M m_{w,}}{A_{m}}, \text { rubles per ton }
$$

5. The smallest possible share of income, taking into account the boundary of operating costs covering operating costs and provides the necessary profit

$$
\operatorname{Rev} \text { min }=\mathrm{P}_{0}+3_{\mathrm{i}} \text {, rubles per ton }
$$

6. The content of mineral components in ore that corresponds to the minimum possible income from the development deposit,

$$
\alpha_{\min }=\frac{\operatorname{Re} v_{\min }}{Ц},
$$

7. When retrieving the enrichment process $\varepsilon$,ore at the site of occurrence should have the minimum possible content $\left(\alpha_{\min }^{\prime}\right)$, providing a minimal profit and economic feasibility of open cast

$$
\alpha_{\min }^{\prime}=\frac{\alpha_{\min }}{\varepsilon}
$$

Input data and calculation results are presented in table 4. 
Table 4. Baseline data and results indicators to determine the lowest possible average mineral constituents in the ore.

\begin{tabular}{|c|c|c|c|}
\hline № & Indicators & $\begin{array}{c}\text { The unit of } \\
\text { measurement }\end{array}$ & Value indicator \\
\hline 1 & Performance of the quarry $\left(A_{P}\right)$ & thousand tons & 8500 \\
\hline 2 & Ore reserves $\left(\mathrm{G}_{\mathrm{P}}\right)$ & $\begin{array}{l}\text { million tons of } \\
\text { ore }\end{array}$ & 250 \\
\hline 3 & Component losses during extraction (p) & $\%$ & 15 \\
\hline 4 & The failover duration deposits $\left(\mathrm{T}_{0}\right)$ & Years & 25 \\
\hline 5 & Extract at enrichment $(\varepsilon)$ & $\%$ & 80 \\
\hline 6 & Investment of rata (I) & million rubles & 120 \\
\hline 7 & $\begin{array}{l}\text { Unit operating costs (according to the deposits- } \\
\text { analogues) }\left(3_{\mathrm{i}}\right)\end{array}$ & rubles per ton & 50 \\
\hline 8 & The price of concentrate (Ц) & rubles per ton & 150 \\
\hline 9 & Annuity factor $\left(b_{n}\right)$ при i $=0,24$ & & 3,78 \\
\hline 10 & Annual profit $\left(\mathrm{OP}_{\mathrm{C}}\right)$ & million rubles & 31,7 \\
\hline 11 & Specific annual profit $\left(\mathrm{P}_{0}\right)$ & rubles per ton & 3,73 \\
\hline 12 & The smallest possible share of income $\left(\operatorname{Rev}_{\min }\right)$ & rubles per ton & 53,7 \\
\hline 13 & $\begin{array}{l}\text { The content of mineral components in ore that } \\
\text { corresponds to the minimum possible income from the } \\
\text { development field } \quad\left(\alpha_{\text {min }}\right)\end{array}$ & $\%$ & $\begin{array}{c}44,7 \\
(35,8)\end{array}$ \\
\hline
\end{tabular}

\section{RESULT}

Described method allows fast enough to take the following decisions:

- on the feasibility of developing an deposit in this average content of useful components in ore;

- about the size of the possible changes in productivity and boundaries to ensure profitability quarries design with low content of useful components.

By analogy to the technique, maybe the definition of the minimum possible, economically expedient performance career for fixed content of minerals in the ore deposits under development.

Among professionals in the mining industry, designers extended fairly dismissive attitude to mining taxes. However, in the context of a market economy, taxes are a heavy burden in expensive parts of the mines affecting the results justify the investment in construction careers.

High taxes on mineral content in extracted ore must be greater than low taxes or lack thereof. Often the subsoil rents payable regardless of profits, is a significant cost element largest career, this applies particularly to energy (e.g., coal).

The tax system of the Russian Federation is in the process of change and reorganization. For certain taxes paid by mining companies to the Federal and local budget, changes the stakes, others are introducing new taxes. The main taxes are value-added tax (VAT), income tax, land tax. In addition, mining companies have been forced to implement current payments and lump- 
sum payments for the right production, for environmental pollution, for reproduction of mineral-raw-material base.

To encourage investments in new mines should impose taxes, which encourages investment, increase or accelerate the rate of depreciation. All major mining countries carried out deductions for exhaustible minerals. The amount of rent for the bowels should be determined by the national mining law. To predict the level of taxes on enterprises and depositsequivalents should access national mountain legislation that provided the consulates and embassies of foreign countries.

\section{THE DISCUSSION OF THE RESULTS}

When designing career, most of the original data is stochastic in nature, including rules and tax payments. If the project starts to be interesting only because there are tax concessions or loopholes in the tax laws, sharply increases the risk of financial and economic decisions on the likelihood of profit from the development.

May reduce tax expenditures deductibility of certain parts of the capital investment of the basic tax rules, i.e. depreciation. Depreciation rates are developed mining countries part of tax legislation, as a rule, these data in detail can be obtained from the above-mentioned sources and publications.

There are two main method of determining depreciation-calculation of linear and non-linear depreciation:

a) If you define straight-line depreciation total investment in mining should be divided by the number of years in the period of depreciation. The result is the annual depreciation rate.

b) when calculating the nonlinear depreciation (depreciation with reduced balance sheet) the depreciation rate is decreasing from year to year, table 5.

For example, consider the total investment in mining in the amount I = 1200 million rubles. Depreciation rate $\mathrm{D}=20 \%$, with the declining balance. Annual depreciation values develop along progressive depression, table 5.

If straight-line depreciation and the same source data (for $\mathrm{n}=15$ years practicing career) depreciation rate

$$
\begin{aligned}
D_{L}= & \frac{I}{n}, \\
& D_{L}=\frac{1200 \cdot 10^{6}}{15}=80 \cdot 10^{6} \text { rubles per year }
\end{aligned}
$$

Table 5. Non-linear depreciation over time practicing career.

\begin{tabular}{|c|c|c|}
\hline Years & $\begin{array}{c}\text { The basis for calculating depreciation, } \\
\text { million rubles }\end{array}$ & $\begin{array}{c}\text { Non-linear depreciation, million } \\
\text { rubles }\end{array}$ \\
\hline 1 & 1200 & $240(20 \%)$ \\
\hline 2 & $1200-240=960$ & 192 \\
\hline 3 & $960-192=768$ & 153,6 \\
\hline 4 & $768-153,6=614,4$ & 122,9 \\
\hline 5 & $614,4-122,9=491,5$ & 98,3 \\
\hline 6 & $491,5-98,3=393,2$ & 78,6 \\
\hline 7 & $393,2-78,6=314,6$ & 62,9 \\
\hline & & \\
\hline
\end{tabular}


The data presented in the table. 5 show that nonlinear depreciation the first five years the amount of depreciation more than linear. As noted above, current profit in the first years of operation of the quarry is especially powerful effect across the economy project. Higher depreciation reduces the costs of depreciation and thus increase the net current profit (NC) improves the economic performance of the project. Because nonlinear depreciation never reaches $100 \%$, then the residue depreciation was postponed to the last year of the operation of the quarry.

Another important aspect of holding investments in building career justification is a form of financing design, construction and development of career. Equity ratio (equity) to borrowed funds is the utilization of the funds borrowed $[10,11]$. To analyze the impact of funding modalities to assess the feasibility of developing the following example we use the: Project open pit mining has a rate of return IRR $=15 \%$ for the whole period of refining offshore. The ratio of its own (equity) capital to borrowed funds taken as (1/3) k (2/3) and interest payments only $10 \%$. The difference between $15 \%$ interest (interest rate) and $10 \%$ perspiration spent to service loan funds earned in this case is added to the equity. Thus have increased the triumphs of rate of return (IRR) approximately $(2(5 \%)=10 \%$ to $25 \%$. Leverage ratio may also have the effect of reserve. If the project has a low rate of return, such as $6 \%$, with $2 / 3$ leveraged funding and $10 \%$ interest, the interest must be paid, despite this low level. The difference (I-IRR) $=10-6=4 \%$ should be deducted from equity ( $1 / 3$ of the total capital). Therefore, the rate of return of the native (equity) capital approximately can be defined as 6-(2 (4) $=-2 \%$, i.e. project can be estimated as the loss in data conditions in different contexts.

\section{CONCLUSION}

The following example shows that the variation coefficient of leverage can significantly improve the economic performance of their own (equity) funds. In special cases (when the proportion of equity approaching zero) it is possible to achieve infinitely large values for the coefficient of use of borrowed funds, provided that the project rate of return (IRR) is greater than the cost of borrowed funds. It is therefore advisable to calculate the original rate of return (IRR) without IP coefficient of use of borrowed funds. If the implementation of a mining project on a $100 \%$ funded by equity, the computation of the rate of return on equity is not necessary.

\section{References}

Arsentiev, A.I., Performance quarries. Saint-Petersburg: State mining institute(technical university, 2010. pp: 85. Burenina, G., analysis of the risks of industrial enterprise. Saint-Petersburg: SPBGUEF.. 2009.

Kerzner, H., Project management a systems approach to planning, scheduling, and controlling. New York: John Wiley. 2009.

Kruk M.N. ,Nikulina A.U. Economic estimation of project risks when exploring sea gas and oil deposits in the Russian arctic / International Journal of Economics and Financial Issues, № 6, V 2, 2016, pp. 138 - 150.

A Guide to the Project Management Body of Knowledge, (2010). In Project Risk Management (Vol. 11). Project Management Institute. ISBN: 1933890711

Surface and underground mining. (2013). In Bureau of Mines cost estimating system handbook (p. 631). U. S. Bureau of Mines.

Meredith, J.. \& Mantel, S. Project management a managerial approach (8th ed.), Hoboken. N.J.:Wiley. $2012,589$. ISBN: 0470533021, 9780470533024, LCCN: 2011292704

Hill J.H. Geological and economical estimate of mining projects. London.1993

Semenov, A. Assessment of project risk in the hierarchical organization of the process of design of complex technical systems. World Applied Sciences Journal. 30(8).2014. 1080-1082. ISSN 1818-4952 DOSI Publications. 2014 DOI: 10.5829/idosi.wasj.2014.30.08.14114 
Semenov A. S. ,Kuznetsov V. S. Assessment of level of risk in decision-making in terms of career exploitation / International Journal of Economics and Financial Issues, № 5, V 1, 2016. pp. 165 - 172.

Qi, E. Proceedings of 20th International Conference on Industrial Engineering and Engineering Management theory and apply of industrial engineering. Heidelberg: Springer.2013 ISBN 978-3-642-40063-6, DOI

10.1007/978-3-642-40072-8 